\title{
Chiasmal visual loss after retinal detachment
}

Figure Perimetry testing and CT imaging
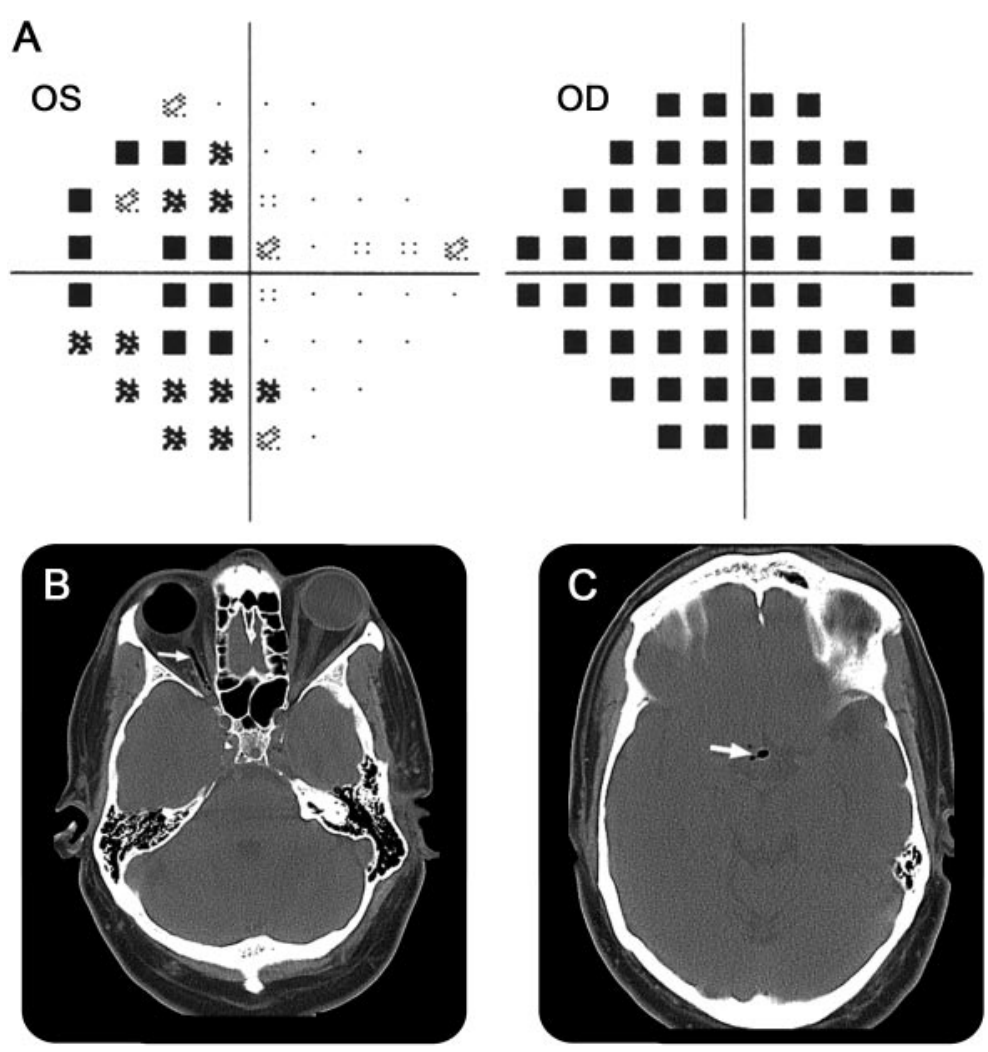

(A) Perimetry testing demonstrated reduced sensitivity in the temporal field of the left eye (contralateral to the retinal detachment). (B, C) A CT scan revealed gas within the right globe, tracking through the right optic nerve into the optic chiasm (arrows). Gas was also present in the lateral ventricles.

A 52-year-old man developed severe vision loss in the right eye due to a large retinal detachment. Vitrectomy was performed in that eye, with 15\% C3F8 perfluoropropane gas injected into the posterior chamber. ${ }^{1}$ He transiently regained hand-motion acuity. Posterior chamber paracentesis was performed for elevated intraocular pressure; endophthalmitis was treated with intraocular antibiotics. After 1 week, blurred vision occurred in the left eye, with intact central acuity and a temporal field deficit (figure). CT imaging demonstrated migration of intraocular gas into the optic nerve and chiasm. Chiasmal visual loss is a rare complication of pneumatic retinopexy.

Sashank Prasad, $M D$, and Alexandra Golby, MD, Boston, $M A$

Study funding: Supported by an American Academy of Neurology Clinical Research Training Fellowship (S.P.).

Author contributions: Dr. Prasad conceptualized the report, collected data, and composed the manuscript. Dr. Golby conceptualized the report and edited the manuscript.

Disclosure: Dr. Prasad reports no disclosures. Dr. Golby serves on the editorial board of Brain Imaging and Behavior; has a patent pending re: Tissue characterization device; receives research support from Nexstim Oyand and the NIH; and holds stock in Merck Serono and Johnson \& Johnson.

Correspondence \& reprint requests to Dr. Sashank Prasad: sprasad2@partners.org

1. Chan CK, Lin SG, Nuthi AS, Salib DM. Pneumatic retinopexy for the repair of retinal detachments: a comprehensive review (1986-2007). Surv Ophthalmol 2008;53:443-78. 


\title{
Neurology
}

\author{
Chiasmal visual loss after retinal detachment \\ Sashank Prasad and Alexandra Golby \\ Neurology 2012;78;150 \\ DOI 10.1212/WNL.0b013e31823efd22
}

\section{This information is current as of January 9, 2012}

\section{Updated Information \& Services}

References

Subspecialty Collections

Permissions \& Licensing

Reprints including high resolution figures, can be found at: http://n.neurology.org/content/78/2/150.full

This article cites 1 articles, 0 of which you can access for free at: http://n.neurology.org/content/78/2/150.full\#ref-list-1

This article, along with others on similar topics, appears in the following collection(s):

Embolism

http://n.neurology.org/cgi/collection/embolism

Optic nerve

http://n.neurology.org/cgi/collection/optic_nerve

Visual fields

http://n.neurology.org/cgi/collection/visual_fields

Visual loss

http://n.neurology.org/cgi/collection/visual_loss

Information about reproducing this article in parts (figures,tables) or in its entirety can be found online at:

http://www.neurology.org/about/about_the_journal\#permissions

Information about ordering reprints can be found online:

http://n.neurology.org/subscribers/advertise

Neurology ${ }^{\circledR}$ is the official journal of the American Academy of Neurology. Published continuously since 1951, it is now a weekly with 48 issues per year. Copyright Copyright (? 2012 by AAN Enterprises, Inc.. All rights reserved. Print ISSN: 0028-3878. Online ISSN: 1526-632X.

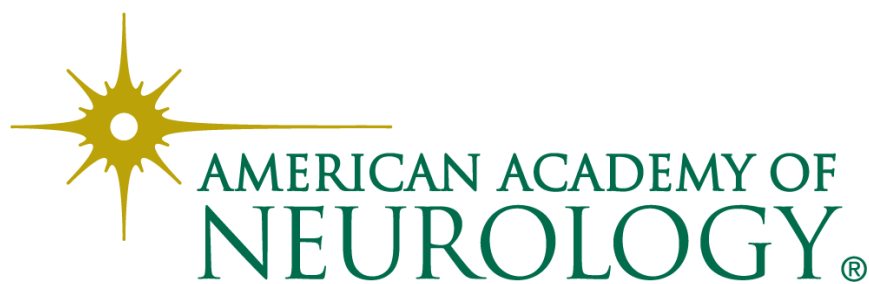

